\title{
An Analysis of the Cognitive Constraints of Parody in the Context of Network Media*
}

\author{
CHANG Yan \\ Qingdao University of Science and Technology, Qingdao, China
}

\begin{abstract}
The language used in the context of network media features variation, flexibility, and comprehensiveness, in which parody is one of the most employed devices. Modern cognitive science prefers to take parody as a cognitive act rather than a sheer linguistic modification act, which has provided a new prospective for further research about parody in the context of network media. This paper aims to probe into the cognitive constraints in the mechanism of parody in the context of network media, in hope to make a detailed explanation of the cognitive process of it and to strengthen the comprehension and appreciation of it.
\end{abstract}

Keywords: parody in the context of network media, cognitive constraints, cognitive realm

\section{Introduction}

A parody, an allusive imitation of another production or practice, may be found in art or culture, including literature, music, and cinema. Parodies in the context of network media are even colloquially referred to as spoofs or lampoons by means of humorous or satiric imitation. Parody in network language can be more vivid, lively, persuasive, humorous, or ironical.

Traditional linguistics takes parody as a rhetorical device, concerning the structure, classification, and the rhetorical effects, while with the development of the linguistic study, modern cognitive science prefers to take it as a cognitive act rather than a sheer linguistic modification act.

Conceptual integration theory can offer a detailed description and profound explanation of the cognitive construction of parody used in the context of network media, which opens up a broader prospect for studying parody used in the context of network media. Parody is actually a psychological generating process, which is complicated. With the reference to the theory and the study of semantic and pragmatic features about parody used in the context of network media, this paper aims to probe into the cognitive constraints during the cognitive process.

\section{Parody in the Context of Network Media}

The following is the case study of parody in the context of network media with detailed explanation.

\footnotetext{
${ }^{*}$ Acknowledgements: This paper is one of the achievements of a project sponsored by the Research of Humanities and Social Sciences of Colleges and Universities in Shandong Province in 2015 of Shandong Provincial Education Department (No. J15WD39) (本文系山东省教育厅立项的 2015 年度山东省高等学校人文社科计划项目(项目编号 J15WD39)的成果之一).

CHANG Yan, lecturer, master, School of Foreign Language Studies, Qingdao University of Science and Technology.
} 


\section{Example (1) "The First Gentleman"}

As we all know, when Bill Clinton was the president of the United States, his wife, Hillary, was the "First Lady", which is defined as "an unofficial title used for the wife, spouse or hostess of a non-monarchical head of state or chief executive" in the dictionary. They were known as "the First Couple" and their family were usually referred to as "the First Family" by the public. Actually, Hillary Diane Rodham Clinton is known as an ambitious politician who is now competing for the presidential selection, and she is a no mean contestant for the big campaign. It was reported that on a diplomatic occasion in China before her declaration of the participation, Bill Clinton said he hoped to see a lady president within his lifespan, and he thought Hillary was "the most competent and the most capable civil servant" in his mind, although he was not sure whether she would run for the Selection or not, "because there is not absolute thing in politics". As her husband, his words before Hillary's following running for the president were something of hype. If Hillary wins the selection one day, Bill Clinton, as the male spouse of the Governor, can be referred to as "The First Gentleman", as an imitation of "The First Lady", which is very impressive and also very accurate.

\section{Example (2) Let's Advertise!}

Let's Get Married (《咱们结婚吧》) is a popular love comedy in 2015. The TV series tell the story of four upcoming wedding couples, concerning on the happenings, conflicts, and stories of the only last week before their actual marriage. Due to the excited plots and excellent performances of the stars, directors, and produces, this TV series has made a big hit among the young audience in China. However, since the story is about family life and marriage life, the careful netizens have figured out that there are approximately several dozens of commodities which have been inserted into the program as indirect advertisements and commercials, like everything from clothing to food and transportation and housing. Many brand names have been listed on the "Acknowledgments" at the end of each episode, which can cover more than four screens. Meticulous netizens exclaim that the name of the TV series should be altered to "Let's Advertise!", which is obviously a parody of the original name with a sense of ridicule and vividness.

\section{Example (3)}

新群歌《常回群看看》

找点空闲, 找点时间, 床上一躺, 到群里看看。

带上好奇, 带上爱恋, 打开流量, 世界上转转。

群主搭建了迷人的平台，群友们关系亲密无间！

喜人的乐事大家分享，恼人的麻烦大家分担！

常回群看看, 回群看看, 哪怕只发张笑脸聊聊天,

我们不图为群做多大贡献呀, 大家都不容易, 就图个快乐平安!

Example (3) is a typical illustration of spree by network language users based on a popular song, the Chinese name of which is “《常回家看看》”. This example demonstrates the welcome of the team members to the chatting group, which is just like the warm welcome of the old parents who hope their married children can spare some time from work and come back to the original home and get together with them more frequently.

Similar spoofs and excitement are often enjoyed once a popular song, a buzzword, or a hot expression comes into being. For instance, after 2014 CCTV Spring Festival Gala, a moving ballad named "Juanlianzhu" by the singer, HUO Zun, became a beloved song with great popularity. Frustrated by the big haze and frog due to the heavy air pollution in China, netizens have created a revised version with the theme of environmental 
protection. The moving lyric song has been totally adapted into a "Divine Comedy of Haze" which also won great welcome by the public.

\section{Example (4)}

“你来，或者不来，我就在这里”。

"Whether you come or not, I will be there. Neither sad nor happy".

In 2014, Obama has visited the Asian-Pacific region, but China was not in his trip, which became a piece of sensitive information for the world, involving the relationship between two countries. Some critics commented the exclusion was deliberately aimed at China, which is a powerful competitor on the global stage. This illustration was Chinese spokesman QIN Gang's reply about those comments in the press conference on April 28, 2014. Actually it is a parody, with the imitation of a lyric poem, written by Zahiram Dodo, a faithful Buddhist. The following is a part of her poem entitled “Meet Me or Not” (《见或不见》):

你见, 或者不见我, 我就在那里, 不悲不喜。

Whether you meet me or not, I will be there. Neither sad nor happy.

你念, 或者不念我, 情就在那里, 不来不去。

Whether you miss me or not, the feeling is still there. Neither coming nor going.

你爱, 或者不爱我, 爱就在那里, 不增不减。

Whether you love me or not, the love is still there. Neither growing nor fading.

你跟, 或者不跟我, 我的手就在你手里, 不舍不弃。

Whether you are with me or not, my hand is in your hand. Neither letting go nor leaving.

来我的怀里, 或者, 让我住进你的心里。

Come into my heart. Or Let me come into yours.

默然相爱,

Silently love each other,

寂静欢喜。

Quietly and joyously.

By altering the main verb with the basic structure remained, this wise parody-reply emphasizes Obama's coming or not to China does not matter so much, China will behave as usual, will insist on our political principle of maintenance of peace, stability, and prosperity in the region, will go on making contribution to the Asian-Pacific area, and will continue shouldering up the responsibility in the world. QIN Gang integrated the beauty in popular literature works with Chinese stance with great wisdom, demonstrating his excellent literacy and his professional accomplishments. More importantly, his intelligent speech showed China's essential confidence to the international world, and also articulated China's political attitude and dignity in the global community, which won every Chinese people's applause and the world's appreciation. From this example, it can be concluded that parody also plays an important role in foreign affairs and international diplomatic occasions.

\section{Example (5)}

山东小伙秦海伟, 有人喊你去结婚!

Shandong guy QIN Hai-wei, someone is calling you to get married!

There has ever been a post on the internet which aroused 200,000 replies within only a single day; this unbelievable phenomenon has been called "a wonder in Chinese language network". In the beginning, it was an anonymous netizen wrote a post entitled "JIA Jun-peng, your mum is calling you to eat dinner back home" with 
no content following. Out of expectation, this normal post had been topped as the first line of almost 7,000 pages! Meanwhile, there came the ripple effect, this post draw great attention from astronomical netizens and uncountable versions of adaptation appeared on the internet, which also electrified hot discussions. In fact, up till now, nobody knows exactly who is "JIA Jun-peng", although cheerful netizens has launched a delighted "human flesh search". More surprisingly, "JIA Jun-peng's grandma”, “JIA Jun-peng's ant”, “JIA Jun-peng's daddy", and so on mushroomed out one by one, which were quickly claimed. Some analysts say this was "a collective game of netizens out of loneliness" and this popular post can recollect netizens' sweet memory as kids when playing with mates in streets, which seldom happens nowadays since the time has changed.

Example (5) is one of the adapted versions of "JIA Jun-peng, your mum is calling you to eat dinner back home". This is what has happened: A girl from Jiangsu Province sent a Wechat message as a marriage proposal, who would like to let her boyfriend "QIN Hai-wei" from Shandong Province finally receive it over great distance through netizens' one-to-one transferring. It turned out that this innovative proposal made the guy the happiest man in the world. As an intriguing report of the romantic story, Example (5) is indeed a parody out of "someone is calling you to eat back home" with great success and public appeal.

\section{Example (6) "Friend Ship" Sinks}

Recently, with the popularity of the "Friend ship' sinks" comic book series on the social networks, linguistic parodies of "Friend ship' sinks" turn out of a hilarity by all netizens of different professions with various versions. The following are some versions of different professions:

A journalist's version: When you have a journalist friend and ask them to have a meal the next day, and they respond that they have to finish a news report, the "friend ship" sinks.

A teacher's version: When your friend is a teacher and you ask if they want to have a meal today and they say "I have schoolwork to do", the "friend ship" sinks...

Obviously, it becomes widespread and numerous netizens regardless of age, profession, and social stature get engaged in this linguistic excitement in social network. On April 6, 2016, the author of Friend Ship Sinks, NAN Dong-ni (喃东尼) even launched a competition of “Ship-sinking Style” (翻船体), which aroused 18,000 times of discussions. The media circle, the IT circle and the public relationship circle all take part in this excitement; the so-called "ship" somehow becomes a "Titanic".

The "tenor" or source language of this parody can be traced back in Friends, a popular American comedy, the dialogue goes as this: "And what is the one kind of boat that can never sink?" "What kind?-A friend ship".

What is more, new parodies with various adaptations emerged on the internet - the Chinese sentence pattern of “N phrase + “说'..... 就' ......” also turns out to be a structure for Chinese network language users for the sake of fun and amusement, which is a great scene of joy for netizens. Here are some examples: “刚领 的工资说没就没”, “刚洗的衣服说脏就脏”, “多好的天气说变就变”. It can be observed from this phenomenon that parodies are very flexible and creative, new parodies may be conjured out of old ones, which bring a lot of conviviality in the context of network media.

\section{Cognitive Constraints}

Parody in the context of network media can strengthen the cognitive and pragmatic effect of network language, and create different cognitive influence on netizens, both of which are greatly based on netizens' successful comprehension of them. However, it has been found that whether network language users can figure 
out the "tenor"- the source text of each parody and whether they can reason out the actual usage and meaning of the "vehicle" - the target text in turn, is mainly determined by some cognitive constraining factors, mainly the subjects' cognitive competence and their cognitive efforts.

\section{Network Subjects' Cognitive Realm}

Effective communication between the addresser and the addressee is usually based on common cognitive context. The broader the common cognitive context or common cognitive realm, the less the communicative efforts will be, and the higher the possibility of correct comprehension and appreciation will be. Network subjects' cognitive realm includes cultural knowledge, encyclopedia knowledge, basic cognition, and logical understanding of network language, common sense, etc. Certain knowledge of the "tenor" of the parody in network media is rather essential for the full appreciation. Accurate recognition of the hidden "tenor" of the parody is the prerequisite. If it cannot be guaranteed, the cognitive reasoning process will be constrained. For instance, as for Example (4), if the subject has never heard of the beautiful lyric, Meet Me or Not, he or she can only analyze the connotation without realizing this is actually a parody. In that case, full and thorough understanding cannot be accomplished. Especially in this world of information expansion, parody in network media can be much more flexible and varied.

\section{Network Subjects' Cognitive Efforts}

Network subjects' cognitive efforts include composition, completion, and elaboration according to the Conceptual Integration Theory, proposed by Fauconnier and Turner. In the process of network parody generation, due to the influence of "tenor's" semantic structure, semantic discrepancy between the "tenor" and the "vehicle" may appear, which requires the network language users' elaboration, reorganization, and composition of the "tenor's" semantic structure, and finally the generation of "vehicle's" semantic structure. As for Example (5), the audience needs firstly the knowledge of "JIA Jun-peng, your mum is calling you to eat dinner back home". Then, the cognitive efforts are required to make to integrate the romantic marriage proposal with the hot sentence structure "Someone is calling you to do something". Only in this way, can the network language users fully comprehend the humor and the amusement of the parody makers.

\section{Conclusion}

Parody, as a kind of rhetorical device in language, is quite flexible. The cognitive act of its creation and comprehension demonstrates complex process. In the context of network media, parodies become more complicated with the engagement of all netizens. Taking the Conceptual Integration Theory as the theoretical base, this paper explores the cognitive process and the cognitive constraints of parody in the context of network media.

Parody in network is a result of cognitive activities of netizens, the comprehension of which demands the cross-space mapping and integration of the invisible "tenor" and the visible "vehicle". The core of the appreciation relies on the possibility of integration in Generic Space, the composition and completion in the Blended Space. The resultant Emergent Structure is the ideal demonstration of the creativity and flexibility of parody in network media, which is full of various information. In the cognitive process of parody in network media, the subjects' cognitive competence and their cognitive efforts are the two essential constraints. 


\section{References}

Fauconnier, G. (1985). Mental space: Aspects of meaning construction in natural language. Cambridge: Cambridge University Press.

Fauconnier, G. (1997). Mappings in thought and language. Cambridge: Cambridge University Press.

Gray, J. (2006). Watching with the Simpsons: Television, parody, and intertextuality. New York: Routledge.

Harries, D. (2000). Film parody. London: BFI.

Hutcheon, L. A. (1985). Theory of parody: The teachings of twentieth-century art forms. New York: Methuen.

Pinker, S. (1994). The language instinct. New York: William Morrow and Company, Inc..

Rose, M. (1993). Parody: Ancient, modern and post-modern. Cambridge: Cambridge University Press.

SUN, Y., \& YANG, Y. (2012). 认知语言学阙域中仿拟的杽乳理据探朢 (A probe into the parody creation motivation from the perspective of cognitive linguistics). 山东外语教学, 5, 26-30.

TAN, Y. X. (1992). 汉语修辞美学 (On aesthetics in Chinese rhetoric). 北京: 北京语言学院出版社.

Ungerer, F., \& Schmid, H. J. (2008). An introduction to cognitive linguistics. Beijing: Foreign Language Teaching and Research Press. 